Hydrol. Earth Syst. Sci., 12, 21-37, 2008

www.hydrol-earth-syst-sci.net/12/21/2008/

(C) Author(s) 2008. This work is licensed

under a Creative Commons License.

\title{
Modelling the water budget and the riverflows of the Maritsa basin in Bulgaria
}

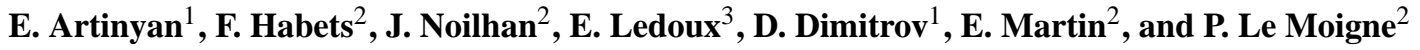 \\ ${ }^{1}$ NIMH-regional centre, 139 Ruski blvd., Plovdiv, Bulgaria \\ ${ }^{2}$ CNRM-GAME (Météo-France,CNRS), 42 Coriolis ave., 31057 Toulouse, France \\ ${ }^{3}$ ENSMP/CIG, 35 St Honoré st., 77305 Fontainebleau, France
}

Received: 8 December 2006 - Published in Hydrol. Earth Syst. Sci. Discuss.: 1 March 2007

Revised: 19 November 2007 - Accepted: 5 December 2007 - Published: 22 January 2008

\begin{abstract}
A soil-vegetation-atmosphere transfer model coupled with a macroscale distributed hydrological model was used to simulate the water cycle for a large region in Bulgaria. To do so, an atmospheric forcing was built for two hydrological years (1 October 1995 to 30 September 1997), at an eight $\mathrm{km}$ resolution. The impact of the human activities on the rivers (especially hydropower or irrigation) was taken into account. An improvement of the hydrometeorological model was made: for better simulation of summer riverflow, two additional reservoirs were added to simulate the slow component of the runoff. Those reservoirs were calibrated using the observed data of the 1st year, while the 2nd year was used for validation. 56 hydrologic stations and 12 dams were used for the model calibration while 41 river gauges were used for the validation of the model. The results compare well with the daily-observed discharges, with good results obtained over more than $25 \%$ of the river gauges. The simulated snow depth was compared to daily measurements at 174 stations and the evolution of the snow water equivalent was validated at 5 sites. The process of melting and refreezing of snow was found to be important in this region. The comparison of the normalized values of simulated versus measured soil moisture showed good correlation. The surface water budget shows large spatial variations due to the elevation influence on the precipitation, soil properties and vegetation variability. An inter-annual difference was observed in the water cycle as the first year was more influenced by Mediterranean climate, while the second year was characterised by continental influence. The energy budget shows a dominating sensible heat component in summer, due to the fact that the water stress limits the evaporation. This
\end{abstract}

Correspondence to: E. Artinyan

(eram.artinian@meteo.bg) study is a first step for the implementation of an operational hydrometeorological model that could be used for real time monitoring and forecasting of water budget components and river flow in Bulgaria.

\section{Introduction}

In recent years, water related problems and their management have become increasingly important in Bulgaria. This is caused partially by drought periods experienced since 1994, but also by the recent inundations and the economic changes. The transition of the country towards a market economic model focuses the attention on a more efficient water use, flood forecasting and mitigation. This increased interest requires more detailed and better founded information in order to provide good support for the decision making system. The needs cover a large number of fields: flood prevention, water availability for the industry, agriculture and cities, water quality management, ecology and climate change. Until now the water budget of the country was mostly studied by using statistical and climatologic approaches. That made it possible to estimate the water budget components for each climatic region of the country. The capacity of this approach however is too limited to offer the level of detail that is necessary for real time evaluation of the surface and groundwater resources.

This paper presents the first attempt to implement a soil-vegetation-atmosphere transfer scheme (SVAT), coupled with a distributed macroscale hydrological model and driven by observed atmospheric forcing for a large region of Bulgaria. The objective of this coupled model is to improve the estimation of the surface water budget (evaporation, soil

Published by Copernicus Publications on behalf of the European Geosciences Union. 


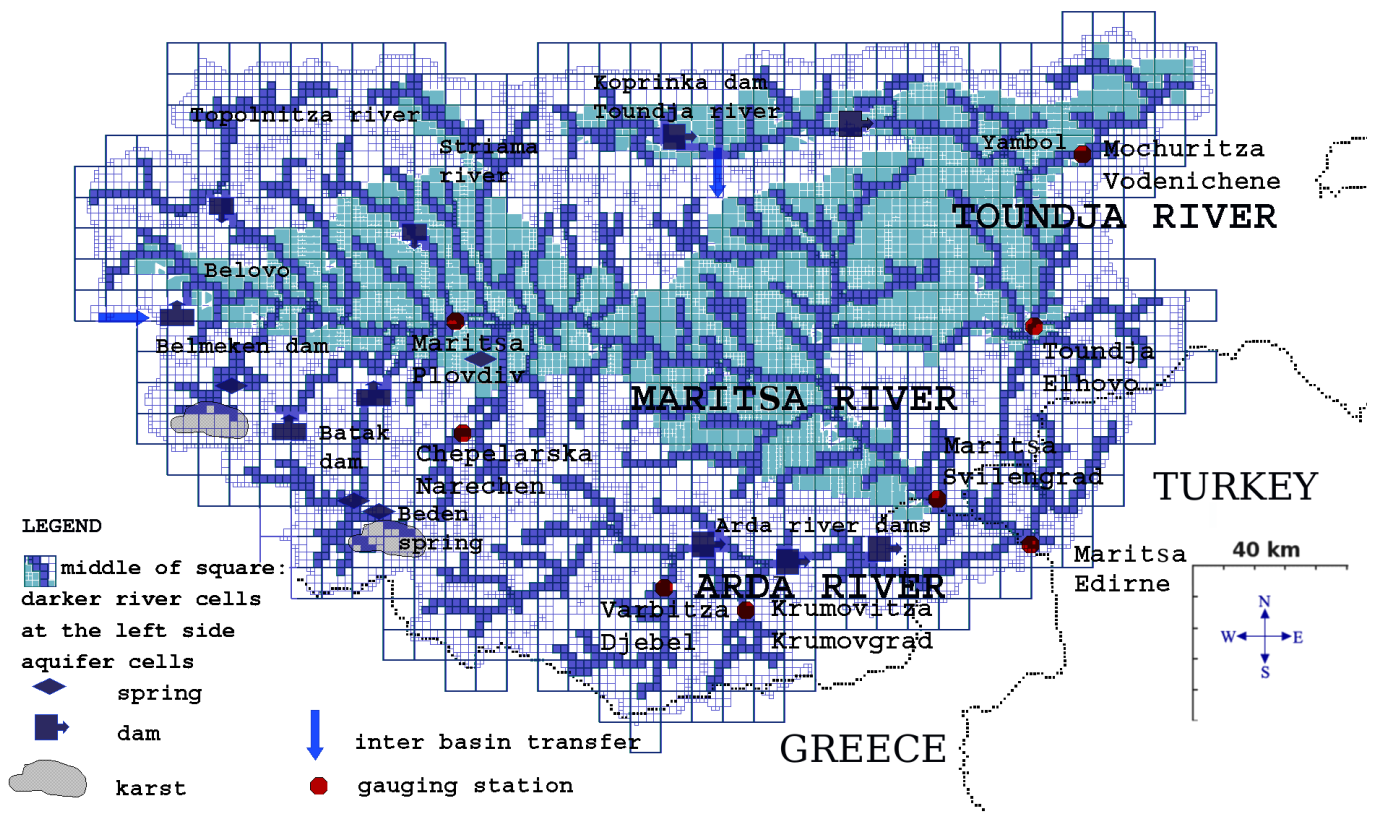

Fig. 1. Surface hydrological network of the Maritsa river system: the river meshes are in dark colour, grey colour represents the aquifer area; dams are shown with dark boxes; the larger springs with diamonds and river gauges with red circles; karstic areas in Maritsa river basin are shown too.

moisture and runoff) consistently with the simulation of the riverflows. It is particularly important to analyse the partition of precipitation into runoff and evaporation based on a realistic description of the land surface conditions (topography, vegetation, soil).

The study is based on the application of the coupled soilbiosphere-atmosphere (ISBA) surface scheme (Noilhan and Planton, 1989) and the MODCOU macroscale hydrological model (Ledoux et al., 1989) which were already applied in three basins in France: the Adour/Garonne basin (Habets et al., 1999a; Morel, 2003), the Rhone basin (Habets et al., 1999b; Etchevers et al., 2000), and Seine basin (Rousset et al., 2004). This paper describes the first application for a region that experiences both continental and Mediterranean climates, with a pronounced dry period in the summer. This allows validating the functioning of the coupled model in different climatic and land cover conditions. After a description of the hydrometeorological characteristics of the Maritsa basin, the ISBA-MODCOU model is presented. The implementation of the hydrological model and modelling results are analysed in the two last sections.

\section{Description of the Maritsa basin: hydrology and me- teorological conditions}

\subsection{Geographic and climatic characteristics}

The Maritsa river basin with its tributaries the Tundzha and the Arda occupies about one third of the land surface of Bulgaria - $34169 \mathrm{~km}^{2}$. The study basin includes a small part on Turkish territory down to the town of Edirne, where two important subbasins (of Arda and Tundzha rivers) reach the main river (Fig. 1) and so the total surface in question becomes $36255 \mathrm{~km}^{2}$. Within Bulgarian borders, the river length is approximately $320 \mathrm{~km}$ with an average slope of 7.7\%. It crosses the border between Bulgaria and Greece and after that, until it reaches the Aegean Sea, the river serves as a natural borderline between Greece and Turkey. Therefore the Maritsa basin is an important water source in South Balkan peninsula, passing through three countries. The elevation of the Maritsa watershed goes up to $2925 \mathrm{~m}$ at the peak of Musala in the Rila mountain. The main geographical structures are the Thracian Valley in the centre, a part of the Balkan mountains (Stara Planina) in the North and the Rila and Rhodopy ranges in the Southwest. The average slope of the Bulgarian part of the basin is $12.5 \%$.

Mediterranean climate influences prevail in the Southeast, where the maximum of precipitation comes in winter. In the central and northern part of the domain the maximum of precipitation occurs in May-June, due to the continental climate influence. 

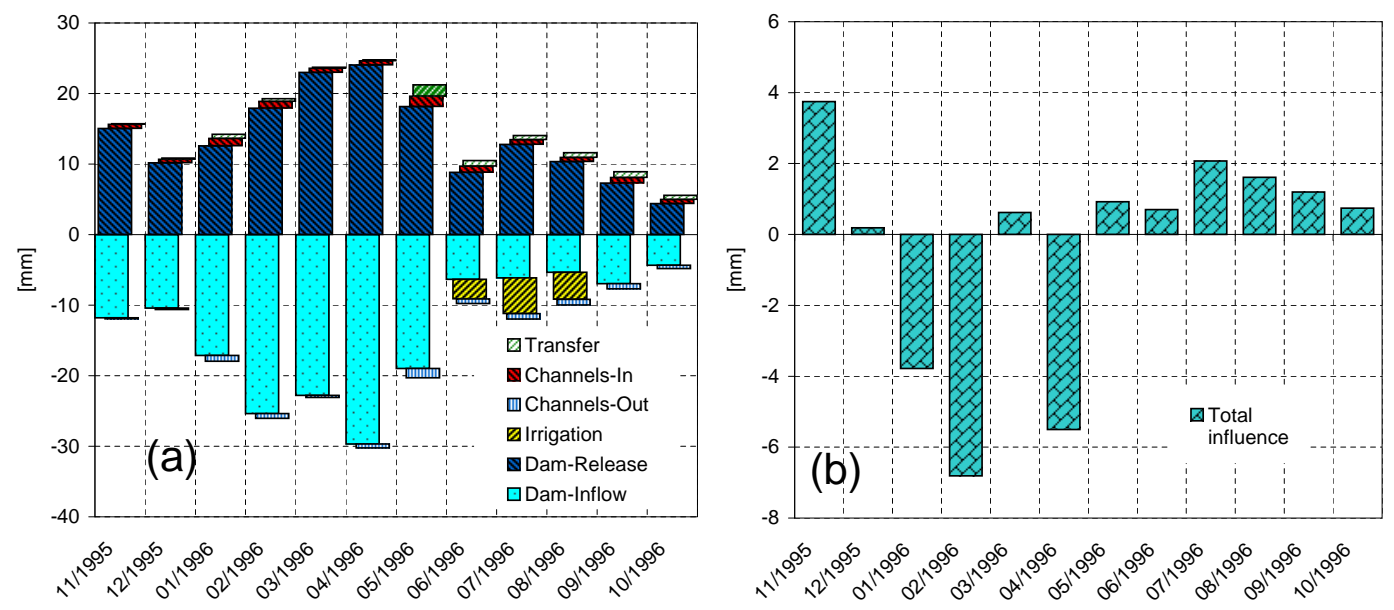

Fig. 2. (a) Monthly budget of the anthropogenic influence on natural riverflow for the entire basin in Bulgaria in [mm]. "Dam-Inflow" the dam reservoirs inflow, "Dam-Release" - the dam reservoirs outflow, "Channels-In" - added water into the riverflow from within Maritsa basin, "Channels-Out" - redirected part of the riverflow within Maritsa basin, "Transfer" - additional water from outside the Maritsa basin, "Irrigation" - water used for irrigation purposes. (b) Overall effect of the anthropogenic influence on natural riverflow [mm].

Annual crops (cereals, vegetables, cotton, and tobacco) and orchards are mainly cultivated in the valleys. The hilly areas are used for pasture, vineyards or to cultivate potatoes. Forests cover about $40 \%$ of the watershed surface. Oak prevails in the valley forests while beech and pine dominate the mountain areas.

2.2 Brief description of the hydrological regime of the surface water and the aquifers

The snowfall in the mountain regions constitutes $30 \%$ to $50 \%$ of total precipitation. Snow cover lasts 73 to 170 days, for the Rhodopy, Stara Planina and Rila mountains (Vekilska and Kalinova, 1978). Based on long term climatological data, the mean annual water budget components for the whole country are as follows: precipitation $-690 \mathrm{~mm}$, runoff $-176 \mathrm{~mm}$ and evaporation $514 \mathrm{~mm}$ (Zyapkov, 1982). The annual averaged streamflow of the Maritsa river varies between $40 \mathrm{~m}^{3} \mathrm{~s}^{-1}$ and $190 \mathrm{~m}^{3} \mathrm{~s}^{-1}$ for the period from 1936 to 1975 . During the summer, the streamflows are very low. Between July and September, the dams and the ground-water outflows mainly sustain the riverflows.

Unconfined aquifers are another specific feature of the study region. The larger aquifer is situated in the Upper Thracian Valley. It covers an area of about $6710 \mathrm{~km}^{2}$ (Kalinova, 1982) between the three main mountain ranges. This aquifer is widely used for irrigation, industrial and domestic water supply. The average outflow of the main aquifer is about $12 \mathrm{~m}^{3} \mathrm{~s}^{-1}$ while its total storage is about $10.9 \times 10^{9} \mathrm{~m}^{3}$. In the valleys of Kazanlak and Sliven, other smaller basins have total reserves of about $1.14 \times 10^{9} \mathrm{~m}^{3}$ and $0.740 \times 10^{9} \mathrm{~m}^{3}$ respectively (Antonov and Danchev, 1980).

Many karstic areas affect the streamflow in the Rhodopy Mountain. They have a well developed system of under- ground flow, caves and emerging springs (Fig. 1). For the period 1980-1996, the average discharges of the four biggest springs, Kleptuza, Beden, Devin and Tri Voditzi were respectively $0.40,0.69,0.53$ and $1.12 \mathrm{~m}^{3} \mathrm{~s}^{-1}$ (Machkova and Dimitrov, 1999). Those perched mountainous (karstic) aquifers are partially contributing to the main water table in the Upper Thracian Valley, especially from the northern slopes of Rhodopy Mountain. The average annual underground transfer to the plain aquifer is estimated to be $12 \times 10^{6} \mathrm{~m}^{3}$, while $47 \times 10^{6} \mathrm{~m}^{3}$ are emerging at the surface as springs (Troshanov, 1992).

\subsection{Anthropogenic influences}

During the years between 1950 and 1970 more than fifteen dams were built in the southern part of the country for better control of the riverflow. The total capacity of the main reservoirs exceeds $2810 \times 10^{6} \mathrm{~m}^{3}$ and their overall drainage area exceeds $12800 \mathrm{~km}^{2}$. Although few of them serve as interannual flow regulators, they usually hold the peak flow in the winter-spring seasons and release water to produce energy and for irrigation in the summer. Most often the dams are built on the riverbed but in few cases, water is supplied by artificial channels. Figure 1 shows the location of the main dams in the basin. The other main anthropogenic influence is the direct use of water from the river for irrigation. There are also cases of transferring water from one river basin to another. For example, after the Koprinka dam on the Tundzha River, a catchment takes water for irrigation and hydropower producing purposes and transfers it into the basin of Sazliika river that is not tributary of Tundzha River. Figure 2a presents the effect of different cases of anthropogenic influence on the riverflow for the period 11/1995 to 10/1996. The most important impact is a result of the dams' water storage 


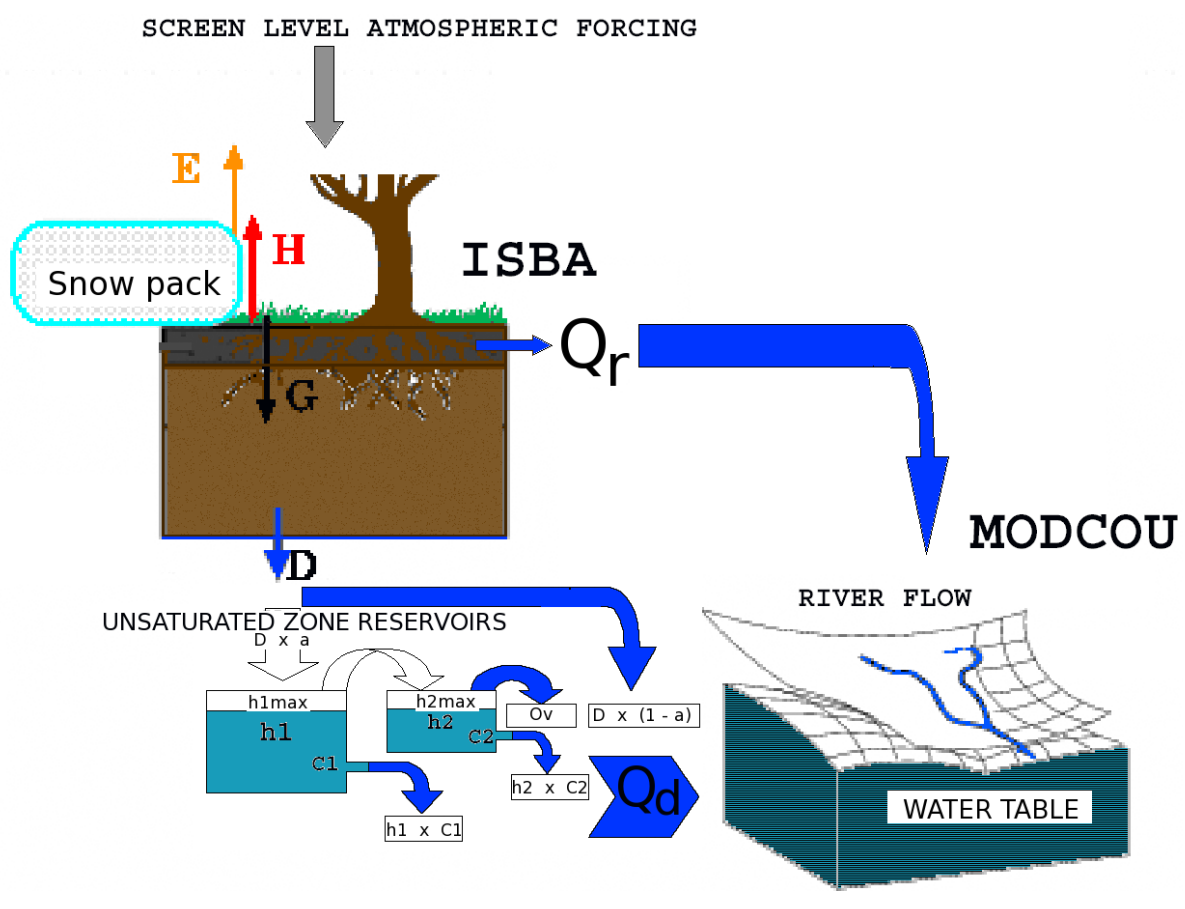

Fig. 3. Scheme of the ISBA - MODCOU coupled model with the 2 additional reservoirs for the drainage, representing the unsaturated layer: $H$ - sensible heat flux, $L E$ - evaporation (latent heat) flux, $G$ - ground heat flux, $D$ - ISBA drainage, $Q r$ - ISBA surface runoff, $Q d$ - final drainage.

and release. From June to November the dams' contributions represent from $1 \%$ to $33 \%$ of the riverflow while in January, February and April they store 25 to $27 \%$ of the streamflow. Although their annual balance is compensated, they play a considerable role in the monthly partition of the riverflow. For the same period, the water used for irrigation is about $12 \mathrm{~mm}$ that is almost $7 \%$ of the riverflow. The amount of water transferred from other basins is about $4 \%$ of the streamflow. The overall monthly impact of human influence on the natural streamflow for the period 11/1995 to $10 / 1996$ is shown in Fig. 2b. Section 4.2 provides details on the implementation of the anthropogenic influence in the simulation.

\section{The ISBA-MODCOU model}

\subsection{Description of ISBA land surface scheme}

The ISBA surface scheme was developed for the mesoscale and large-scale climate models as well for the weather prediction models used at Météo-France. It represents the main surface processes in a relatively simple way: it solves one energy budget for the soil and vegetation continuum, and uses the force-restore method to compute energy and water transfers in the soil. A representation with two soil layers is used - a shallow surface layer and a root zone (Fig. 3). Four components are used to compute the evaporation: interception by the foliage, bare soil evaporation, transpiration of the vegetation, and sublimation of the snowpack.

Two fluxes of water in the soil are computed: surface runoff $\left(Q_{r}\right)$ and drainage $(D)$ (Fig. 3). Subgrid heterogeneities of the soil moisture are involved only in the surface runoff. To evaluate the subgrid runoff, the concept of the Variable Infiltration Capacity (VIC) (Dûmenil and Todini, 1992) is used. It considers that a fraction of the cell is saturated, and thus, can produce surface runoff, even if the whole cell is not saturated. This fraction is almost zero when the soil is dry (around the wilting point), and is going up to $100 \%$ when the whole cell is saturated. It is varying according to an exponential function, which is based on a shape parameter $(b)$.

In this application, the snow pack is represented by one layer with uniform temperature, density and water content (Douville et al., 1995).

\subsection{Description of the concept of additional reservoirs for the drainage flow}

The previous applications of the coupled ISBA-MODCOU model were done for relatively wet regions, without pronounced dry periods. In the case of the Maritsa river during the dry period of the year the runoff is mostly sustained by the deep soil drainage and the aquifer, where it exists. The process occurring in the unsaturated zone, between the soil 
root-zone and the water table, makes a significant contribution to the total runoff especially in the summer.

In the two-layer soil scheme, used in this application, water transfer in the unsaturated zone below the root-zone was not implemented. For a better simulation of the hydrodynamics of streamflow, two additional reservoirs were introduced, between the surface scheme ISBA (that includes a root-zone) and the MODCOU hydrological model (Fig. 3), assuming there is at least two distinct parts in the unsaturated flow below the root zone. The first one is directly fed by the drainage from the root zone of ISBA. This reservoir has two outflows: one is reaching the river, and plays the role of a baseflow by maintaining the summer flow, although the fraction of this flow is rather weak, and thus gives relatively low discharge values. The second outflow occurs when the first reservoir reaches a maximum value, and has therefore no time-lag compared to the drainage simulated by ISBA. This outflow is feeding the second reservoir, that represents a less compact and more fissured upper area of the geological profile (below the root-zone). Therefore, the second reservoir has a higher depletion coefficient and is emptied within few weeks. This reservoir has again two outflows: one overflow, and one percolation flow. This last flow is controled by a depletion speed, and plays an intermediate role between rootzone flow (as part of ISBA) and the first unsaturated zone reservoir flow. In the mountain area, where aquifer layer does not exist, these two additional reservoirs allow an accurate simulation of the time lag of the drainage water during the transfer in the unsaturated zone.

It has been assumed that the slower reservoir is filled up first, which ensures the low flow in dry conditions. However a more detailed implementation would include a minimum level of the faster reservoir, to be reached, before passing water to the slower one.

A fraction $\alpha$ of the gravitational drainage water that is simulated by ISBA (D), is used to feed the reservoirs (Fig. 3). First this water goes to the reservoir with water content $h_{1}$ and a depletion coefficient $C_{1}$ that is relatively low in order to induce large time delay for the outflow. When its maximum level $h_{1}$ max is reached, water surplus is transferred to the second reservoir, which has a higher depletion coefficient $C_{2}$, leading to a shorter time delay for the reservoirs ouflow. When the second reservoir level $h_{2}$ reaches its maximum $h_{2}$ max, extra water leaves the reservoir. Thus, the drainage part of the runoff is expressed by Eqs. (1) and (2):

$Q_{d}=D \times(1-\alpha)+Q_{o v}+h_{1} \times C_{1}+h_{2} \times C_{2}$

with $Q_{o v}=D \times \alpha-\left(h_{2} \max -h_{2}\right)$

Therefore the five parameters of the additional reservoirs are: $\alpha$ - coefficient controlling the drainage water input into the reservoirs

$h_{1} \max , h_{2} \max -$ maximum levels of the reservoirs

$C_{1}, C_{2}$-depletion coefficients of the reservoirs, $C_{1} \leq C_{2}$
$Q_{d}$ is transferred either to the riverflow where there is no aquifer or to the aquifer simulated by MODCOU. The part of it that passes through the first reservoir $\left(h_{1} \times C_{1}\right)$ may be considered as the slower part of drainage. The additional reservoirs are processed at the time step and using the grid of the hydrological model. The higher resolution of the hydrological grid gives the possibility to calibrate the parameters by use of nested subbasins, which is described in Sect. 5.2.2. The river gauges define embedded basins. Thus the parameters have to be attributed first to the outlet and then upwards to the next smaller nested basin. The variability of the parameters could be related to the geomorphic characteristics (elevation, slope) or to the geologic profile, if such information is available.

\subsection{Description of MODCOU}

The macro-scale hydrological model MODCOU has been used in various applications (Ledoux et al., 1989). MODCOU considers the surface and underground layers. The surface routing network is computed starting with the topography, by using a geographical information system. The surface and underground domains are divided into grid cells of embedded size (from 1 to $4 \mathrm{~km}$ ), the higher resolution being associated to the river grid cells. The transfer time between two grid cells is associated with the topography, the distance between the cells and the surface of the basin. The surface runoff computed by ISBA is routed to the river network and then to the river gauges using isochronous zones with a daily time step. The drainage computed from ISBA and from the new drainage module contributes to the evolution of the water table, which evolves according to the diffusivity equation. Exchange of water between the aquifer and the river are computed according to simple relations (Ledoux et al., 1989). At the end, the flows from the surface layer and from the aquifer form the riverflow at the gauging stations.

\section{Implementation of ISBA-MODCOU in the Maritsa basin}

\subsection{Hydrological parameters}

The hydrographical surface network as well as the underground layer grid were established by using a GIS based on the topography (Golaz et al., 2001). For that purpose, the GTOPO30 database (provided from USGS EROS Data Centre) was used. The grid consists of 11661 meshes in the surface layer, including 2387 river cells; and 4390 cells for the underground layer (Fig. 1).

\subsection{Implementation of dam reservoirs in the simulation}

Data about the water budget of twelve reservoirs and about water redirecting and channelling were available only for the first year of simulation. They were used first to check the 
simulated streamflow at the dam entrance and, second, to impose dam ouflow to the simulated streamflow downstream the dam.

In the simulation, all the streamflows that are downstream from the dams or the stream diversion points were corrected in order to take into account the impact of these structures on riverflow. The method is considering that the first upstream reservoir inflow is the "natural" flow, therefore this simulated "natural" flow is subtracted from each simulated downstream station riverflow with respect to the time lag between the dam's river cell and the corresponding station cell. Secondly the dam's outflow data provided by the dams' managers are added to each downstream station riverflow again with respect to the time lag. After, the same procedure is conducted with the next downstream dam, etc. In the northern part of the basin, the observations showed that the outflows from irrigation dams did not sustain the riverflow in summer. Those outflows were redirected through irrigation channels (Fig. 2a). Therefore, this part of the streamflow $(11.7 \mathrm{~mm}$ or $7 \%$ ) was subtracted from the simulated streamflow. At the basin level, the overall effect of anthropogenic influence for the period 1 November 1995 to 30 October 1996 was about $-4 \mathrm{~mm}$, and almost $7 \mathrm{~mm}$ was transferred from other basins (Fig. 2a).

\subsection{Surface parameters}

The ISBA parameters can be determined from soil texture and vegetation maps using tables of correspondence, as detailed in Noilhan and Lacarrere (1995).

The vegetation map compiled by Champeaux and Legléau (1995) from the NDVI archive distinguishes 12 vegetation types. The resulting vegetation map shows that the single Forest class is the dominant vegetation type in the mountains. In the valleys, the "Mediterranean region cereal", associated with dry summer conditions, is dominant. The monthly evolution of leaf area index (LAI), vegetation cover (VEG), and roughness length $\left(z 0_{v}\right)$, were related to the 2 years' satellite archive of the advanced very high resolution radiometer/normalized difference vegetation index (AVHRR/NDVI), following the method presented in Habets et al. (1999a). The minimum surface resistance $\left(R_{s m}\right)$ and albedo $\left(\alpha_{v}\right)$ are constant in time and linked to the vegetation type (Champeaux and Legléau, 1995).

In the study detailed maps of the soil properties - the percentage of sand and clay as well as the soil depth map were used to obtain data at $1 \mathrm{~km}$ resolution. The mapped soil depth is enough realistic for the mountain forests in Bulgaria (Ninov, 1982). The soil depth values used in this study varies between $40 \mathrm{~cm}$ and $150 \mathrm{~cm}$. Only the forested regions in the valleys have deeper soil $-180 \mathrm{~cm}$.

\subsection{Atmospheric forcing}

\subsubsection{Meteorological database}

To compute the water and energy cycle the ISBA surface scheme needs 8 atmospheric parameters: rainfall and snowfall, air temperature and humidity at $2 \mathrm{~m}$, wind velocity, atmospheric pressure, global radiation and atmospheric radiation. Such a database was assembled for 26 months (from 1 August 1995 to 30 September 1997). The atmospheric forcing was prepared at a 3-h timestep, but the precipitation data were collected on a daily basis. To be consistent with the density of the observation network and the hydrological grid, an $8 \times 8 \mathrm{~km}$ grid cell was used to interpolate in space the atmospheric forcing. This meteorological grid consists of 638 cells (Fig. 1). The next two sections present the preparation of the atmospheric parameters needed for the modelling.

\subsubsection{Snow and rain precipitation, air temperature}

The point scale observations were interpolated in space using two software packages. The spatial interpolation of the temperature was made with software dedicated to scattered data, statistically linked to the topography, the Aurelhy method (Benichou and Le Breton, 1987). However, when the temperature field was not sufficiently correlated with elevation, due to atmospheric temperature inversion that appears most often in winter time, the kriging software Bluepack was preferred (Delfiner et al., 1978). The combination of two methods yielded better results that the sole use of the Aurelhy method.

The precipitation field has high spatial variability. Where the rain gauges with different measured values are too close, the Bluepack kriging method gives noisy results. The analysis showed that interpolation quality depends on the average distance between two stations for the whole field. This has led to the "averaging neighbours" method: where the distance between two precipitation stations is less than the required minimum, the average of the observed values of the two gauges is attributed to both stations before the interpolation. For the Rhone basin precipitation field, the minimum tolerable distance was $2 \mathrm{~km}$ (Artinian, 1996). In the case of the Maritsa river basin, where the rain gauges are scarce, this distance was determined to be $6 \mathrm{~km}$. The resulting precipitation fields showed a good agreement with the climatological maps of precipitation for a given season (Hershkovich et al., 1982).

\subsubsection{Atmospheric radiation and global radiation}

To compute the atmospheric radiation the formula of Staley and Jurica (1972) was used. It takes into account the air temperature, air specific humidity and cloudiness.

For the global radiation, few observations were available: only two stations had measured directly the global radiation at a hourly time step. Measurements of the bright 
sunshine hours were made at 15 sites, using a CampbellStokes recorder, which allows the estimation of the "bright sunshine ratio" i.e., the ratio of the actual duration of bright sunshine to the maximun possible duration of bright sunshine. Global radiation depends on the elevation, because of the impact of the aerosol concentration on the atmospheric transmittance (Hottel, 1976) and air turbidity. To take into account such impact, as well as all the available data, we used a modified version of the parameterisation suggested by Kasten and Czeplak (1979). It is based on a statistical relation between the hourly global radiation, the hourly bright sunshine ratio, and the 3-hourly cloudiness, observed at the different sites. It is expressed as follows (Eq. 3)

$R g=R g_{0} \times\left\{A_{1} \times\left(1-0.88\left(\frac{N b}{10}\right)^{3.5}\right)+B_{1} \times \frac{A l t i}{1000}+C_{1} \times S u n\right\}$

where $R g$ stands for the hourly global solar radiation $\left(\mathrm{Wm}^{-2}\right), R g_{0}$ stands for theoretical clear-sky global radiation computed according to the solar elevation angle at sea level (Kasten and Czeplak, 1979), $\mathrm{Nb}$ stands for the average hourly cloudiness (varying from 0 to 10), Alti stands for the altitude of the grid point $(m)$, Sun stands for the hourly bright sunshine ratio, ranging from 0 to 1 and $A_{1}, B_{1}, C_{1}-$ are empirical coefficients

The atmospheric parameters were computed for two hydrologic years - 1995/1996 and 1996/1997. The maps of the atmospheric forcing for the two years show a large spatial variability. The total accumulated precipitation (liquid and solid) is marked by strong values in the mountain areas, but the higher values for the second year are situated in the Southeast, where the more pronounced Mediterranean climate can produce intense rainfall. In the valleys the annual value of total precipitation varies from 400 to $600 \mathrm{~mm}$, while in the mountains it varies from 700 to $1300 \mathrm{~mm}$. Snowfall is more important in the mountains. It varies from $10 \mathrm{~mm}$ in the valleys to $800 \mathrm{~mm}$ in the Rila Mountain.

\section{Modelling results}

\subsection{Hydrological database and methodology}

The hydrological database consists of daily streamflow discharge of 56 river gauges. The inflow and release flows data of 12 dams, as well as snow density measurements only for the first year from the National Electricity Company $(N E K)$; and from the Water Management Company (Vodno Stopanstvo) for the northern part of the basin were obtained. From the total number of 68 stations and dams, only 41 could be used for statistical comparisons, because for 10 stations and 12 dams no data was available for the validation year. Additionally, five small catchments (smaller than $50 \mathrm{~km}^{2}$ ) were discarded from the comparison because there was a $10 \%$ error between the reported land surface area of the subbasin and the modelled one. In order to check the quality of the simulation, three statistical criteria were computed for each gauging station: the ratio between simulated and observed annual discharge $Q \operatorname{sim} / Q o b s$, the daily efficiency $E$ (Nash and Sutcliffe, 1970), and the coefficient of determination $-R^{2}$. To achieve perfect simulation these three statistical numbers should be equal to 1.0. The ratio $Q \operatorname{sim} / Q o b s$ gives an estimation of the annual partitioning of the precipitation into runoff and evaporation, whereas $R^{2}$ indicates if the simulated and the observed streamflow are significantly correlated. On the other hand, the efficiency $E$ is an intermediate criterion more sensitive to the good estimation of high flow.

In the following sections, the method of calibration of the model parameters is presented, and the results in terms of streamflow, snow height, soil moisture, and water and energy budgets are discussed.

\subsection{Calibration of model parameters}

\subsubsection{Calibration of the shape parameter}

The calibration of the shape parameter used in the subgrid runoff scheme was performed by using its relation to the altitude, as presented in Eq. (4). This dependency account for the higher relative contribution of the surface runoff at high elevation in mountains due to steeper slopes and shallower soils. When comparing the simulated against the measured riverflow higher efficiency is achieved linking the shape parameter to the elevation.

$b=\left(0.2+\frac{A l t i}{3000}\right) \times 1.4$,

where Alti is the cell elevation [m] and $0.28 \leq b \leq 1.68$.

Equation (4) gives the best modelling results for high flow conditions. The values of $b$ are significantly higher than the values calibrated in an earlier publication (Artinian, 1996). This result is explained with the introduction of additional reservoirs for the drainage flow, after which the efficient simulation of peak flows needs lowering of the precipitation's fraction transferred to drainage reservoirs.

\subsubsection{Calibration of the unsaturated zone reservoirs}

The five parameters of the drainage reservoirs had to be calibrated for each of the 68 subwatersheds. The calibration method consisted of carrying out a series of simulations in which only the value of the parameters for each sub-basin was varied. For each parameter the entire range of values were tested (between its extreme values). After each simulation the statistical results of the comparison between simulated and observed streamflow and the corresponding set of parameter values were stored. At the end the parameters giving the best statistical score for each subwatershed are retained. The extreme values of the parameters were set using the accumulated streamflow volume for the dry period of the year, which is assumed to be close to the average level $h_{1}$ of 

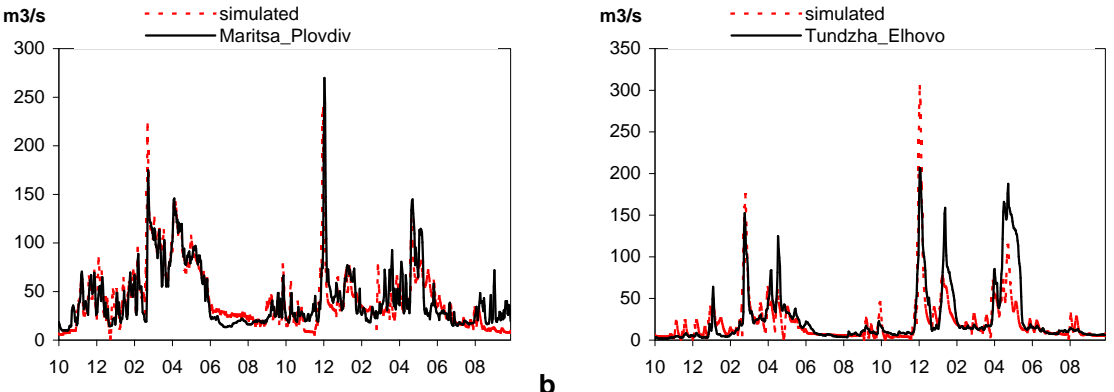

a
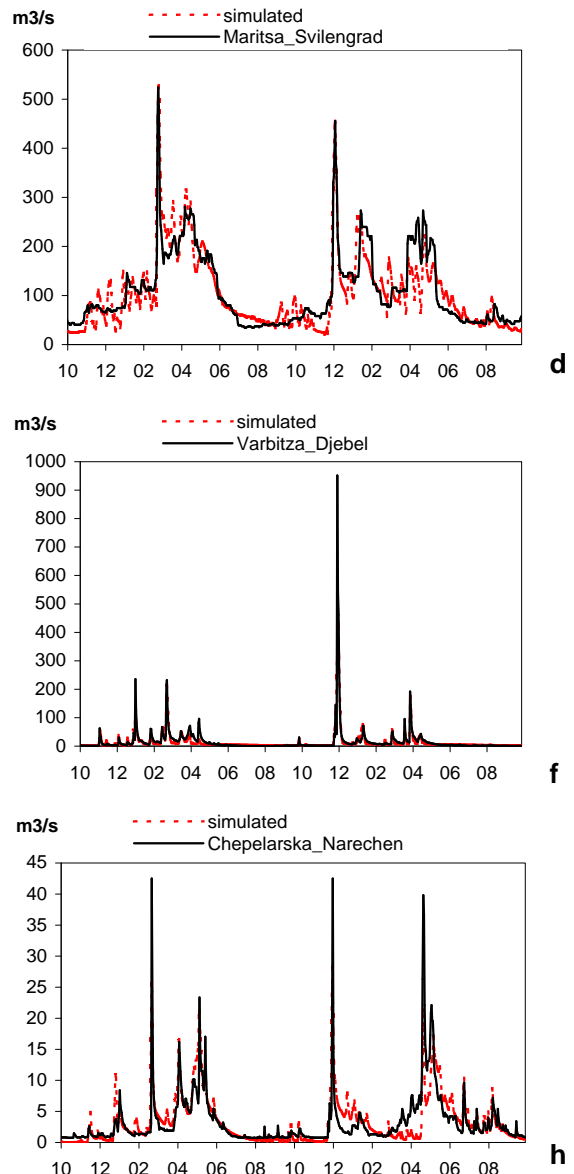
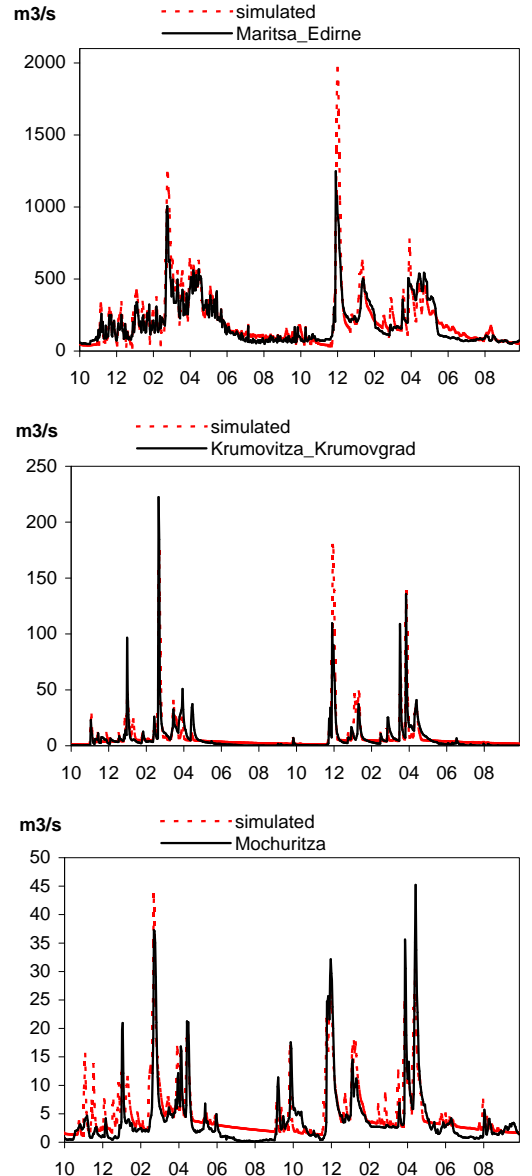

Fig. 4. Comparison of the observed (solid line) and simulated (dashed line) hydrographs for main Maritsa and Tundzha subbasins (a, b, $\mathbf{c}$ and $\mathbf{d})$ and four watersheds not disturbed by human activities (e, f, $\mathbf{g}$ and $\mathbf{h})$ for the calibration (1995/1996) and validation (1995/1996) hydrological years.

the first (slow) reservoir (Fig. 3). It was estimated that the parameter $h_{1} \max$ value is $10 \times Q d r y \geq h_{1} \max \leq \frac{1}{4} \times Q d r y$. For each subbasin, the total volume of the runoff for the dry period of the year - Qdry [mm] was computed. For the calibration year the dry period is easy to estimate from the measured riverflow (Fig. 4). It starts in July and ends in October. As the calibration has been made for each sub-basin with available measured data, Qdry was estimated for each one of the 56 hydrological stations and 12 dams. The limits for the depletion coefficient $C_{1}$ were deducted from extreme values of $h_{1}$ max in order to simulate the average daily streamflow during dry periods. The same range of values was used for the $h_{2}$ max parameter as for $h_{1} \max$. For the limits of the parameter $C_{2}$, we used the relations $C_{1}<C_{2}$ and $C_{2}<0.20$, because, with the value of 0.2 , a reservoir of $h_{2} \max =300 \mathrm{~mm}$ (maximum value found in the previous step) is depleted in about 5 days. The parameter $\alpha$ varies between 0.0 and 1.0.

Table 1 shows the computed average and extreme values of the five parameters. At the end of the calibration phase, the following results were observed, which may be used to link 
the parameters to the basin geomorphological characteristics:

- The valley subcatchments present high values of the $\alpha$ coefficient: $\alpha=0.80$ to 1.0 , which means that only small part of the streamflow is a rapid flow.

- The Southeast part of the basin (Arda and tributaries) shows low rate of drainage water storage: $\alpha=0.05$ to 0.35 . This corresponds to the lower rock permeability in that region.

- By contrast, the subcatchments from regions with pronounced karst development in the Rhodopy Mountain show higher $\alpha$ coefficient: $\alpha=0.75$ to 1.0 than the other catchments with the same average elevation $(\alpha=0.1$ to $0.65)$.

- The lowland subcatchments as well as karstic regions have higher $h_{1}$ max parameter which corresponds to a higher amount of water available for the slow component of the flow.

These observations agree with some published results about the partitioning of the runoff according to its origin - surface, drainage and deep drainage (Yordanova, 1978). However, in many cases the lack of knowledge about the anthropogenic activity leads to errors during calibration. In order to estimate the parameters with great accuracy, detailed information about human activity in the study area is necessary.

\subsubsection{Calibration of the maximum transfer time and aquifer parameters}

A maximum transfer time $T c$ for the water to reach the outlet was established for the Maritsa basin, according to the observed streamflow. As $T c$ is an integer number (days), it was calibrated empirically by running the hydrological model with the more realistic values (between 4 and 7 days). Then the value of $T c$ giving the higher statistical scores when comparing simulated to measured riverflow was chosen: $T c=6$ days.

The evolution of water table is controlled by transmissivity and storage coefficients. Existing publications were used to make a first guess of these coefficients. Transmissivity varies from $1.0 \times 10^{-3}$ to $34 \times 10^{-3} \mathrm{~m}^{2} \mathrm{~s}^{-1}$ while the values of the storage coefficient are between 0.20 and 0.23 (Antonov, 1980). They were calibrated for eight subregions of the unconfined underground layer using the available measured streamflow data for the first modelled year-95/96. As for the unsaturated zone parameters calibration, a cycle of simulations and the corresponding statistical scores permitted to select the final set of parameters for each of the eight different aquifer zones.

\subsection{Results in terms of streamflow simulation}

For the entire study area, the error in the mean annual discharge for the first (calibration) year is lower than $20 \%$ for
Table 1. Average and extreme values of the five parameters for the reservoirs representing the unsaturated zone, calibrated for the year 95-96 with imposed after-dam streamflow.

\begin{tabular}{llll}
\hline Parameter & Average & Maximum & Minimum \\
\hline$\alpha$ & 0.75 & 1.0 & 0.05 \\
$h_{1} \max$ & $60[\mathrm{~mm}]$ & 300 & 5 \\
$h_{2} \max$ & $90[\mathrm{~mm}]$ & 300 & 1 \\
$C_{1}$ & $4.0 \times 10^{-3}$ & $4.0 \times 10^{-2}$ & $1.0 \times 10^{-4}$ \\
$C_{2}$ & $2.5 \times 10^{-3}$ & 0.13 & $1.0 \times 10^{-4}$ \\
\hline
\end{tabular}

half of the stations. On average, the annual simulation for the calibration year is close to the observations for the main stations (overestimation of 13\%). The observed and simulated daily streamflow discharges for 8 river gauges are given (Fig. 4a-d). Their positions are shown in Fig. 1. The value of $E$ is greater than 0.7 for $27 \%$ of the stations and greater than 0.6 for $36 \%$ of them. The best values are obtained for the main rivers (Fig. 4 a to $d$ and Table 2).

For the calibration year, as it could be expected, better results are obtained when the dam inflow/outflow are taken into account (Table 2), except for the annual ratio Qsim/Qobs that is overestimated. This overestimation is due to the underestimation of the fraction of the dam water release that is used for irrigation purposes. This amount should be removed from the simulated riverflow. The influence of imposed streamflow is stronger near to the dams (for instance at Plovdiv) and diminishes downstream (for instance at Svilengrad). It rises again at the outlet (Edirne) because of the proximity to the Arda river reservoir cascade. The lowest efficiencies are computed for the Northwest part of the Tololnitza and Striama watersheds, where the rain gauges are too few.

For the second (validation) year (1996/1997) the efficiency is lower. The value of $E$ is higher than 0.6 for $32 \%$ of the stations, but the error on mean annual discharge remains at the same level - less than $20 \%$ for half of the stations. The lack of data about reservoir inflow/outflow for the second year does not allow appropriate corrections to be made to the affected streamflows. Therefore the third result set of Table 2 (validation) should be compared only with the results from the first year, not corrected with reservoir inflow/outflow (second result set). Twelve gauging stations, not perturbed by dams, have higher statistic results for the validation year than for the year of calibration.

\subsection{Snow simulation}

To validate the snow cover evolution simulated by the ISBA surface scheme, 20 climatological stations were selected according to the following criteria: minimum elevation $450 \mathrm{~m}$, more than 100 days of observed snow cover for the two years, observations available for the entire simulation period and 

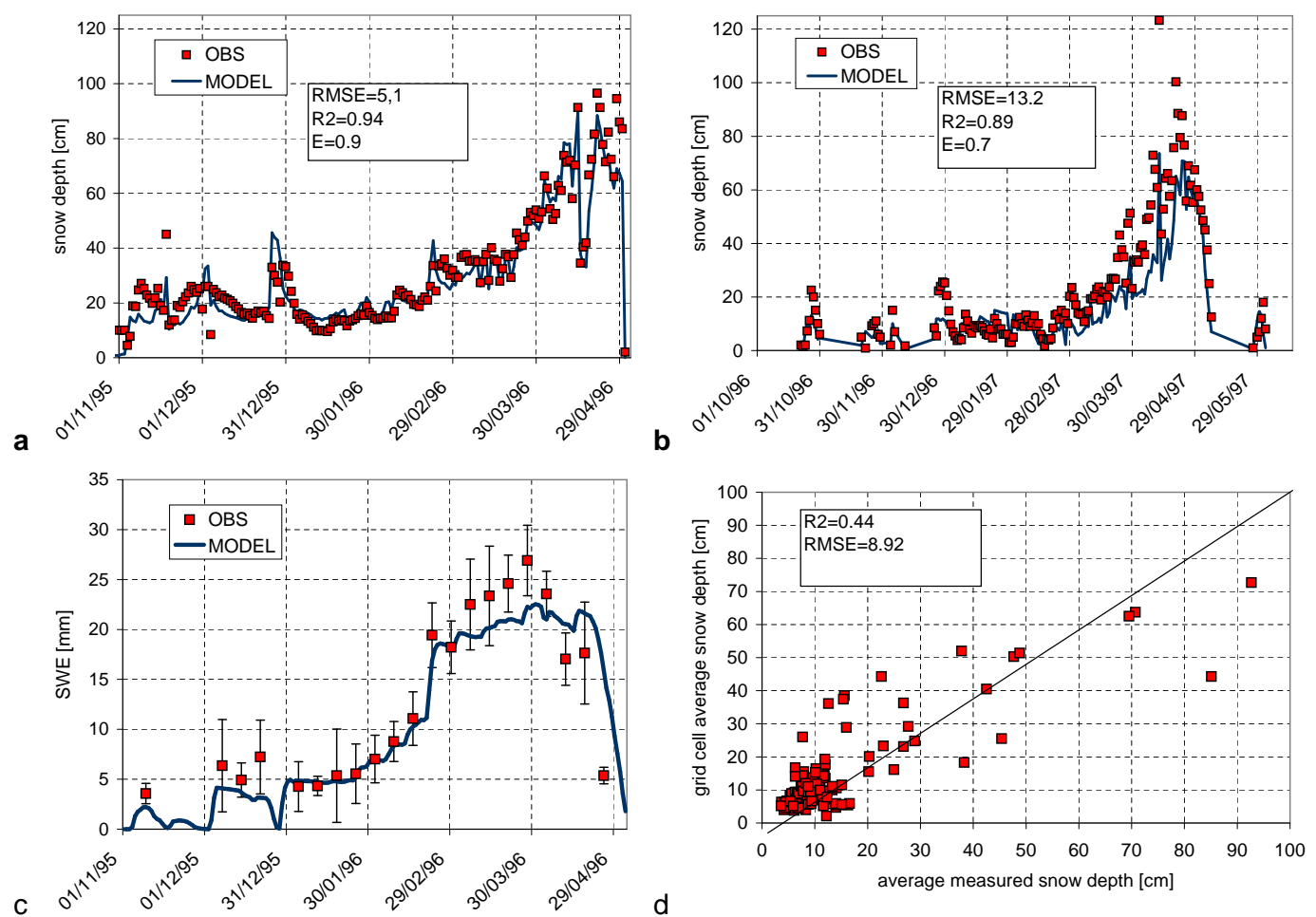

Fig. 5. Snow depth and snow water equivalent $(S W E)$ comparisons: Comparison of the averaged on 20 points of the observed and simulated snow depth [cm] - (a) winter 1995/1996; (b) winter 1996/1997; (c) Comparison of the averaged on 5 sites (SWE) observed and simulated $[\mathrm{mm}](\mathbf{d})$ Scatter plot of the average simulated snow depth $[\mathrm{cm}]$ compared to the average observed snow depth for the whole observation network (174 gauges).

Table 2. Comparison statistics of series of simulated against measured daily streamflow discharge for the main river gauges on Maritsa and Tundzha rivers and four not perturbed by human activity watersheds: Varbitza, Krumovitza, Chepelarska and Mochuritza. Imposed streamflow takes into account streamflow stored in or released from dam reservoirs, taking water from the river bed and flow redirections. $Q s i m / Q o b s$ is the simulated versus observed discharge ratio, $E$ the daily efficiency, and $R^{2}$ the coefficient of determination.

\begin{tabular}{|c|c|c|c|c|c|c|c|c|c|c|}
\hline \multirow[b]{2}{*}{$\begin{array}{l}\text { River, } \\
\text { Gauge station }\end{array}$} & \multirow[b]{2}{*}{$\begin{array}{l}\text { Avg. alti- } \\
\text { tude (m) }\end{array}$} & \multicolumn{2}{|c|}{$\begin{array}{l}\text { Calibration } \\
\text { imposed } \\
(1995 / 1996)\end{array}$} & \multirow{2}{*}{$\begin{array}{c}\begin{array}{l}\text { year with } \\
\text { streamflow }\end{array} \\
R^{2}\end{array}$} & \multicolumn{2}{|c|}{$\begin{array}{l}\text { Calibration } \\
\text { out imposed } \\
(1995 / 1996)\end{array}$} & \multirow{2}{*}{$\begin{array}{c}\text { year with- } \\
\text { streamflow } \\
R^{2}\end{array}$} & \multicolumn{2}{|c|}{$\begin{array}{l}\text { Validation } \\
\text { out imposed } \\
(1996 / 1997)\end{array}$} & \multirow{2}{*}{$\begin{array}{c}\text { year with- } \\
\frac{R^{2}}{\text { d streamflow }}\end{array}$} \\
\hline & & $\begin{array}{l}\text { Qsim/ } \\
\text { Qobs }\end{array}$ & $E$ & & $\begin{array}{l}\text { Qsim/ } \\
\text { Qobs }\end{array}$ & $E$ & & $\begin{array}{l}\text { Qsim/ } \\
\text { Qobs }\end{array}$ & E & \\
\hline Maritsa, Plovdiv & 915 & 1.10 & 0.83 & 0.93 & 0.94 & 0.29 & 0.72 & 0.87 & 0.37 & 0.67 \\
\hline Maritsa, Svilengrad & 582 & 1.04 & 0.84 & 0.93 & 0.96 & 0.84 & 0.94 & 0.91 & 0.70 & 0.85 \\
\hline $\begin{array}{l}\text { Tundzha, } \\
\text { Elhovo }\end{array}$ & 475 & 1.00 & 0.64 & 0.82 & 1.16 & 0.47 & 0.79 & 0.75 & 0.54 & 0.76 \\
\hline Maritsa, whole basin & & 1.16 & 0.75 & 0.95 & 1.02 & 0.65 & 0.88 & 1.10 & 0.47 & 0.86 \\
\hline Varbitza, Djebel & 584 & 0.89 & 0.77 & 0.88 & 0.89 & 0.77 & 0.88 & 0.96 & 0.78 & 0.89 \\
\hline $\begin{array}{l}\text { Krumovitza, Kru- } \\
\text { movgrad }\end{array}$ & 494 & 1.10 & 0.71 & 0.84 & 1.10 & 0.71 & 0.84 & 1.31 & 0.43 & 0.85 \\
\hline $\begin{array}{l}\text { Chepelarska, } \\
\text { Narechen }\end{array}$ & 1356 & 1.09 & 0.72 & 0.87 & 1.09 & 0.72 & 0.87 & 0.95 & 0.59 & 0.77 \\
\hline $\begin{array}{l}\text { Mochuritza, } \\
\text { denichene }\end{array}$ & 259 & 1.38 & 0.50 & 0.78 & 1.38 & 0.50 & 0.78 & 1.06 & 0.70 & 0.84 \\
\hline Average & & 1.09 & 0.72 & 0.87 & 1.07 & 0.62 & 0.84 & 0.99 & 0.57 & 0.81 \\
\hline
\end{tabular}


Table 3. Parameters and modelling results for the observed soil-crop profiles. The second and third columns show the type of crops observed in the sites and the prescribed vegetation types used by the model for the corresponding grid cell. Next two columns show the field capacity $(W f c)$ and wilting point (Wwilt) (values given for $1 \mathrm{~m}$ column depth), as observed and as prescribed in the model. Coefficients of determination of the comparison between simulated versus observed series of normalized soil moisture are given in the last two columns: the first one shows the statistics when all observed crop profiles of the site are considered, while the last column shows the results obtained using only wheat or barley (W\&B) profiles (winter cereals). Plovdiv, Rajevo Konare and Ivailo sites are considered as influenced by irrigation.

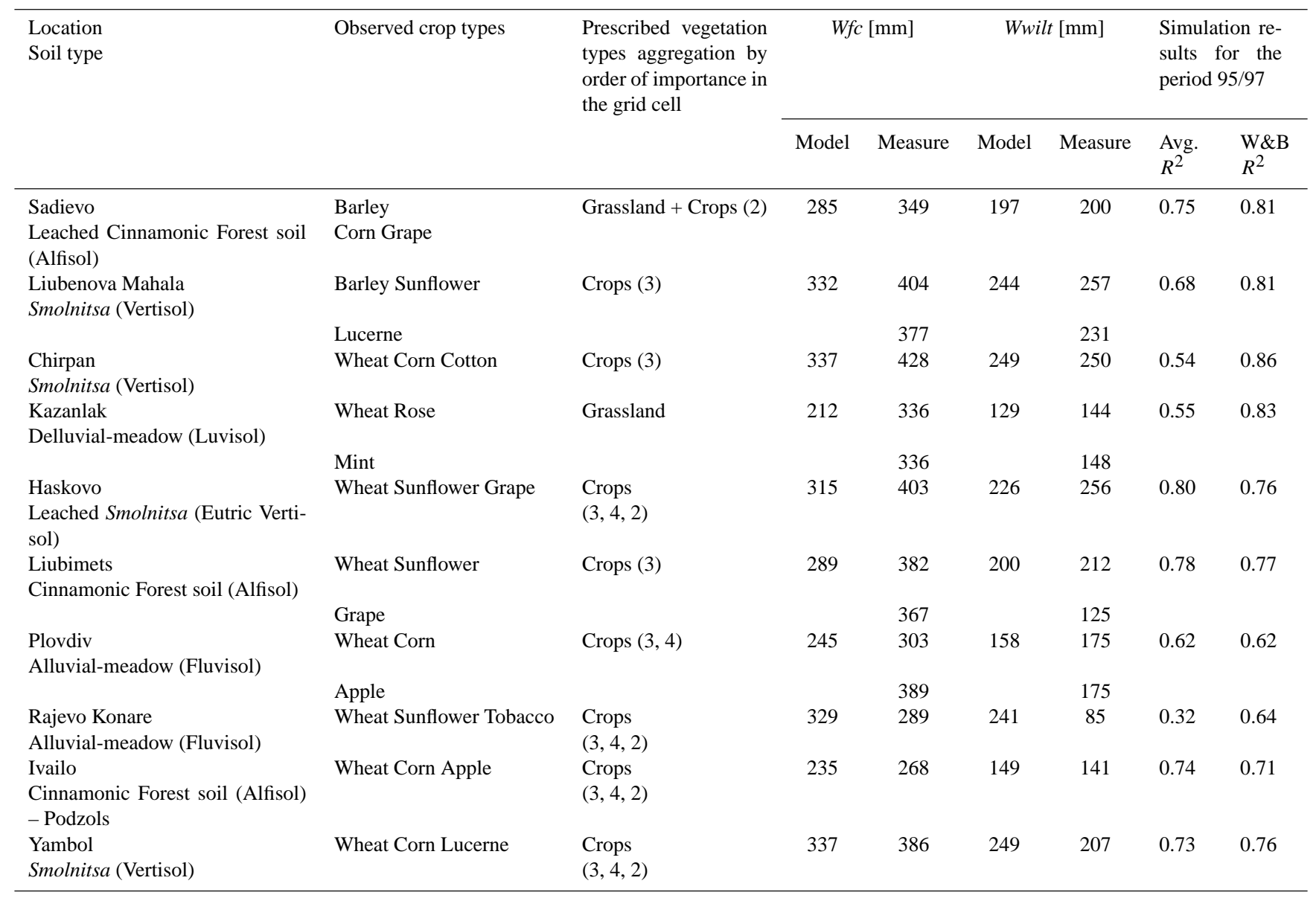

grid cell altitude close to the station's elevation (difference less than $200 \mathrm{~m}$ ). For these stations, the interpolated air temperature is closer to the observed one comparing to stations with only rain/snow measurement. The mean evolution of snow depth for these stations is depicted in Fig. 5a and b. In the second year, the results are poorer and one of the reasons for this is the generally higher temperature in the winter of 1997 (on average for January 1996 it is $-1.64^{\circ} \mathrm{C}$; while for January 1997 it is $+2.01^{\circ} \mathrm{C}$ ). Therefore the melting of the snow pack during the day and the refreezing of the liquid water stored in the snow pack at night happens more often during the second year than the first one. Such a process is not taken into account in the one-layer snow scheme used in this study. It was however simulated by the 3-layer snow scheme recently developed for ISBA (Boone and Etchevers, 2001), and the application of that scheme showed good re- sults for both years. The RMSE for the daily snow depth for the first year of the simulation for these sites is $5 \mathrm{~cm}$ but for the second simulated year it is $13 \mathrm{~cm}$. Observations of the snow pack from 174 stations at a daily step were considered in order to evaluate the quality of snow simulation at the basin scale. A comparison between the averaged observed and simulated snow depth for 174 stations is presented in Fig. 5d. This scatter plot shows the snow scheme efficiency but the result is highly influenced by the quality of air temperature interpolation, which is better in the neighbourhood of the 55 climatological stations.

Snow density together with snow depth data is available for five sites and only for the first modelled winter - 1995/96. The snow density and snow water equivalent $(S W E)$ were compared after averaging the results of corresponding model grid cells and the daily data of five measuring sites (Fig. 5c). 
The model simulates well the snow height and the corresponding water content in cold conditions $\left(T^{\circ} \mathrm{C}<0.0\right)$. In case of rainfall over the snow pack $\left(T^{\circ} \mathrm{C}>0.0\right)$, and periods of melting-freezing, the $S W E$ is strongly underestimated. This is leading to a lower $S W E$ than the observed one, during the less cold period.

\subsection{Soil moisture simulation}

In order to validate the model soil moisture simulation agrometeorological data were collected from 10 stations measuring the soil water content (Table 3).

The measurements of volumetric soil moisture were available from ten agro-climatic stations, each one with three profiles. Agrometeorologists systematically selected the three profiles of each site with different vegetation cover - one with wheat or barley vegetation (winter crops), one with perennial vegetation (e.g. vineyard, rose, etc.) and one with annual vegetation (cotton, lucerne or corn). The measurements were made by weighting the soil sample, extracted three times a month, before and after drying. No measurements were made during the winter season. The soil and vegetation characteristics observed in situ and those used in the simulation for the ten sites are given in Table 3.

The soils in Bulgaria's valleys have often high available water capacity $(A W C)$ (Richards and Wadleigh, 1952). Alluvial meadow soils, for instance, contain high amount of clay - between 40 and $60 \%$ and a corresponding high $A W C$ e.g. 110 to $180 \mathrm{~mm}$ for the top $1 \mathrm{~m}$ soil depth (Dimitrova, 1991), especially where the humus content increases. AWC values computed by ISBA ( 75 to $90 \mathrm{~mm}$ ) are lower than the measurements. To compare the evolution of the observed against the simulated soil water content a normalization of both values was made. Thus, the moisture content computed by the surface scheme is normalized by using Eq. (5) and then compared to the normalized measured top 1-m soil moisture. In the last two columns of Table 3 the statistics of the comparison are given.

$$
W_{n}=\frac{w_{2}-w_{2} \min }{w_{2} \max -w_{2} \min }
$$

where $w_{2}$ min and $w_{2}$ max are the minimum and maximum values of the volumetric water content within the simulation period and $w_{2}$ is the volumetric water content $\left(\mathrm{m}^{3} / \mathrm{m}^{3}\right)$. The analysis of the measured values showed that all profiles of some sites were highly influenced by irrigation, so these stations were discarded from the comparison. As the winter cereals are less dependent on water supply, they are usually not irrigated. Thus, two kinds of validation were made: the first one used the averaged values of all the soil profiles of the seven not-irrigated sites ( 21 profiles) and the second one - only the cereal profiles of these sites, i.e. wheat and barley. The comparison showed that for most profiles, the higher and lower values of observed and simulated soil moisture correlated well over time. The model simulates fast lowering of the soil moisture in April and May, which corresponds to the seasonal behaviour (in terms of soil moisture usage) of the observed winter crops. The results proved that winter cereals observed in situ were properly defined (in terms of soil moisture usage) by the prescribed vegetation types - Crop (3) and Crop (4), except for the period from June to August when soil moisture was depleted faster in the simulation. The possibility that the values of $L A I$ and $V E G$ were fixed at levels which were too low for those months could be the reason for this overestimation of the bare soil evaporation (LEG) (Fig. 7b).

\subsection{Water and energy budgets at the basin scale}

\subsubsection{Surface water budget}

Figure 6 shows the annual maps of accumulated evaporation and runoff for the two years of simulation. The fields have large spatial variability.

The total evaporation is linked to the topography. Accumulated annual evaporation varies from 300 to $780 \mathrm{~mm}$. The highest value $(780 \mathrm{~mm})$ is simulated during the second year in the Rhodopy Mountains. The generally higher values in the mountains are related to the dense forest vegetation, and the more significant rainfall at this altitude.

The annual accumulated runoff varies spatially from $15 \mathrm{~mm}$ to $580 \mathrm{~mm}$ for the first year. During the second year it ranges from 12 to $680 \mathrm{~mm}$. The valleys show the lowest values, while the region of East Rhodopy Mountains is producing systematically the higher runoff. This phenomenon is linked to the combination of several factors: almost no forest, shallow soil and the intense rainfall. While in the forested areas rainfall is subject to retention by the forest litter and the evaporation rate can be high, for the south-eastern part of the Rhodopy mountain flash floods are occurring almost every year. The drainage fraction represents $77 \%$ of the runoff for the first year and 74\% for the second one - respectively 125 and $126 \mathrm{~mm}$ (Table 4). However, almost all of it comes from the mountain area. The drainage in the valleys remains very low because of the high evapotranspiration and its contribution to the aquifer is weak. Exception to that could be the deep infiltration fraction of water used for irrigation.

Monthly values of the water budget (Fig. 7a) show that there are three precipitation maxima during the first year: in November-December, in February and in September. For the second year the maxima are in November, March-April and August. The first year is dominated by the Mediterranean climate (with winter precipitation) while the second year is typical for the continental water cycle. The evaporation follows the temperature variability and the water availability. Thus, it has higher values in April and May (87, $84 \mathrm{~mm}$ ), for the first year, when the two conditions intervene. It is also linked to the development of vegetation. It rises also in September $(61 \mathrm{~mm})$ with the increase of precipitation. The bare ground evaporation $(L E G)$ causes the September rise while in the other cases (Fig. 7b) the plant transpiration (LETR) 
Table 4. Annual water budget for some main gauging stations and four watersheds not impacted by human activities: Ptot - total precipitation [mm]; Psnw - snow precipitation [mm]; Etot - total evaporation [mm]; Qtot - total runoff [mm]; Dw - evolution of soil water storage [mm]; Eg - evaporation from the bare soil [mm]; Er - plant interception evaporation [mm]; Etr - plant transpiration [mm]; Es sublimation/evaporation at the snow surface [mm]; ISBA drainage $D$ and surface runoff $\operatorname{Qr}$ [mm]; Storage in the snow pack is neglected for all the watersheds as the simulation ends on 30 September, when snow pack rarely exists.

\begin{tabular}{|c|c|c|c|c|c|c|c|c|c|c|c|c|c|}
\hline River, (sub-basin) & 1995-1996 & Surface & Ptot & Psnw & Etot & Qtot & $D w$ & $E g$ & Er & Etr & Es & $D$ & $Q r$ \\
\hline Maritsa, Svilengrad & & 21379 & 598 & 174 & 430 & 140 & 28 & 174 & 91 & 136 & 29 & 105 & 35 \\
\hline Tundzha, Elhovo & & 5549 & 651 & 128 & 484 & 120 & 48 & 193 & 101 & 166 & 24 & 83 & 37 \\
\hline Chepelarska, Narechen & & 412 & 765 & 317 & 460 & 283 & 21 & 149 & 122 & 120 & 70 & 223 & 61 \\
\hline Varbitza, Djebel & & 1144 & 751 & 162 & 381 & 359 & 11 & 167 & 85 & 114 & 15 & 293 & 66 \\
\hline River, (sub-basin) & 1996-1997 & Surface & Ptot & Psnw & Etot & Qtot & $D w$ & $E g$ & $E r$ & Etr & Es & $D$ & $Q r$ \\
\hline Maritsa, Edirne (whole basin) & & 36255 & 652 & 105 & 513 & 171 & -32 & 206 & 97 & 193 & 16 & 126 & 45 \\
\hline Maritsa, Svilengrad & & 21379 & 603 & 106 & 510 & 125 & -32 & 207 & 92 & 193 & 18 & 87 & 38 \\
\hline Maritsa, Plovdiv & & 8077 & 595 & 149 & 519 & 112 & -36 & 203 & 102 & 184 & 31 & 75 & 37 \\
\hline Mochuritza, Vodenichene & & 1190 & 654 & 62 & 594 & 139 & -79 & 215 & 106 & 266 & 7 & 98 & 42 \\
\hline
\end{tabular}

represents the larger fraction of the total evaporation. In summer, transpiration is lower (30 and $20 \mathrm{~mm}$ ) because of the water stress. For the second year the total evaporation $(L E)$ is higher by about $100 \mathrm{~mm}$ (Table 4), caused by the spring and summer precipitation together with the higher temperatures in that season. The runoff variability is linked to the same processes. When winter precipitation occurs, it contributes to the runoff because of the low evaporation. On the other hand, a large part of the spring and summer precipitation will evaporate before contributing to runoff.

Figure 7 shows the impact of the added drainage reservoirs on the basin monthly water budget. Figure 7 a shows that during four consecutive months of 1996 and one month in 1997 there is practically no water available for the runoff (sum of both surface runoff and root-zone drainage). Figure 7c shows that unsaturated zone reservoirs during those months are not empty, thus supplying flow to the rivers.

The soil water content rises for the first year between October and December, then in February and decreases very fast from March to May (Fig. 7c). For the period from June to September the soil reservoir water content rises with about $100 \mathrm{~mm}$. For the second year the process of replenishment is shorter but more intensive in winter. The depleting occurs one month later due to the spring precipitation. Figure $7 \mathrm{c}$ shows that the unsaturated zone reservoir plays an important role in the water budget as well.

The water budget is highly influenced by the contrast be- tween the valleys and the mountain areas of the region. However, part of this contrast is hidden by the dams' impact on the runoff. Mountainous catchments are highly influenced by the snowmelt. On the opposite, the Arda river and its tributaries, which are under Mediterranean influence, are not affected by snow. Table 4 shows the components of the water budget of four main subbasins and also of four smaller watersheds that are not disturbed by anthropogenic activity. For the entire basin the relation between evaporation and precipitation $(E / P)$ is about 0.7 for the first year and 0.8 for the second. In comparison the mountain catchments (Fig. $4 \mathrm{~g}$ ) have values between 0.6 and 0.65 , which is due to the snowmelt feeding and low temperatures. Southeast Rhodopy Mountain tributaries - Vurbitza and Krumovitza rivers (Fig. 4e and f), show lower values of that parameter: 0.43 and 0.51 . The shallow soils, intensive precipitation and the lack of forests in the region explain this phenomenon.

\subsubsection{Aquifer water budget}

At the basin scale, the plain aquifer makes a relatively small contribution to the runoff. That is partially due to the small amount of infiltration in the area with aquifer layer. As that layer covers the valleys where the evapotranspiration takes large part of the precipitation, only small part of the infiltration water reaches the water table. The aquifer maintains the riverflow with $19 \mathrm{~m}^{3} \mathrm{~s}^{-1}$, or $6 \%$ of the total streamflow, which agrees with published data (Antonov and Danchev, 


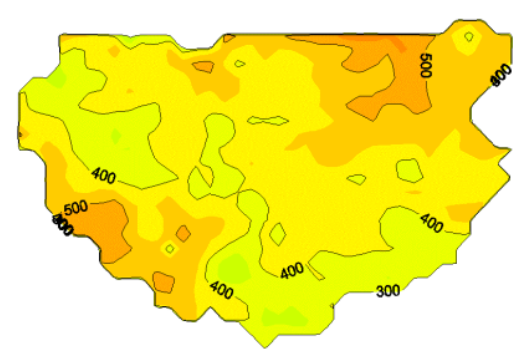

a

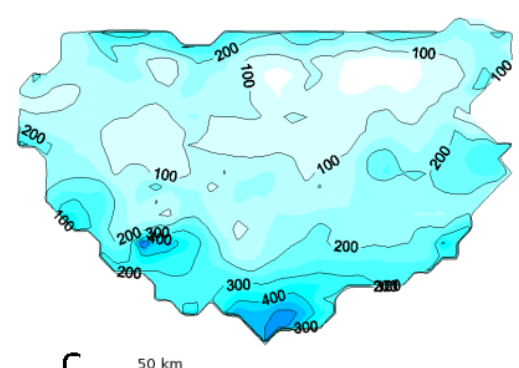

$\mathrm{C}$

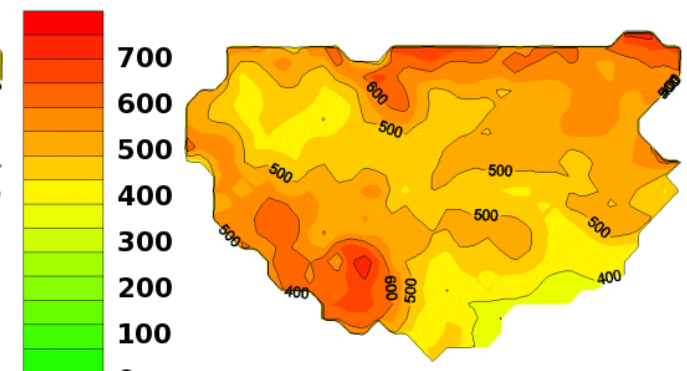

b

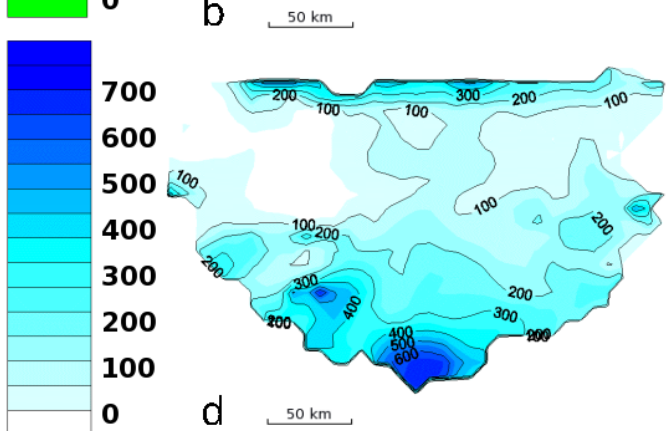

Fig. 6. Annually accumulated fields for the water budget components to the left for 1995/1996 and to the right for 1996/1997: (a-b) Total evaporation $[\mathrm{mm}]$; (c-d) Runoff $[\mathrm{mm}]$.

1980). The recharge occurs mainly in winter and spring months at a rate of 6-7 $\mathrm{mm}$ per year. The monthly aquifer budget is positive only for March 1996. The two-year's budget is negative, about $-10 \mathrm{~mm}$. This corresponds to a decrease of water table level. Recharges by infiltration of irrigation water and lateral underground recharge are not taken into account.

\subsubsection{Energy budget}

The energy budget is linked to the water budget by the evapotranspiration term and is expressed by the Eq. (6):

$R_{n}=H+L E+G$

where $R_{n}$ stands for the net radiation flux, $H$ and $L E$ stand for the sensible and latent heat fluxes and $G$ stands for the ground heat flux. The annual variations of these fluxes are driven by the net radiation flux. The monthly budget of the study area, for the two years of simulation, is presented in Fig. 8a. $R_{n}$ varies between 15 and $130 \mathrm{Wm}^{-2}$. The higher values are in June-August - over $115 \mathrm{Wm}^{-2}$ for the two-year simulation, while the lower values are in the period November-February - below $25 \mathrm{Wm}^{-2}$. The evaporation fluxes vary from 8 to $70 \mathrm{Wm}^{-2}$ between the winter and spring months. The higher values are in spring because the evaporative demand of the atmosphere coincides with the water availability in the soil. In summer, the latent heat is lower than the sensible heat because of the lack of water for evaporation. During the second year, more water is available in summer and the two main components of the energy budget are closer. The ground heat flux has its maximum values in March-May - 4.3-4.5 $\mathrm{Wm}^{-2}$. The dominating sensible heat flux in summer months is due to two main reasons: the lack of precipitation and the prescribed vegetation type with low values of the vegetation fraction in summer. The Bowen ratio $(H / L E)$ for the first year is equal to 1.36 and to 0.92 for the second one.

Figure $8 \mathrm{~b}$ shows the energy balance components averaged for the two modelled years compared to the published values (Vekilska, 1982)(Lingova, 1981), converted into $\mathrm{W} \mathrm{m}^{-2}$, for the country as a whole. The published climatological values of ratio $L E / R_{n}$ vary between 0.42 and 0.70 (in average 0.46 in the simulation). The published values of the relation $H / R_{n}$ are between 0.30 and 0.45 (in average 0.52 in the simulation) while the ground heat flux is positive from March to August.

Lingova (1981) evaluated the energy balance components semi-empiricaly for 65 meteorological stations. The method used for estimating these components over land is based on the energy conservation law. The energy balance is estimated as difference between the net energy absorbed by the vegetation-soil system and the outgoing longwave radiation. These two components are evaluated from measured or empiricaly computed incident solar radiation, surface albedo, measured soil and air temperature, air moisture and nebulosity. Energy used for evapotranspiration is also estimated empiricaly with use of soil moisture data and computed potential evaporation. Direct measures of the energy balance components made at the Sofia meteorological observatory are used to check the method localy. 

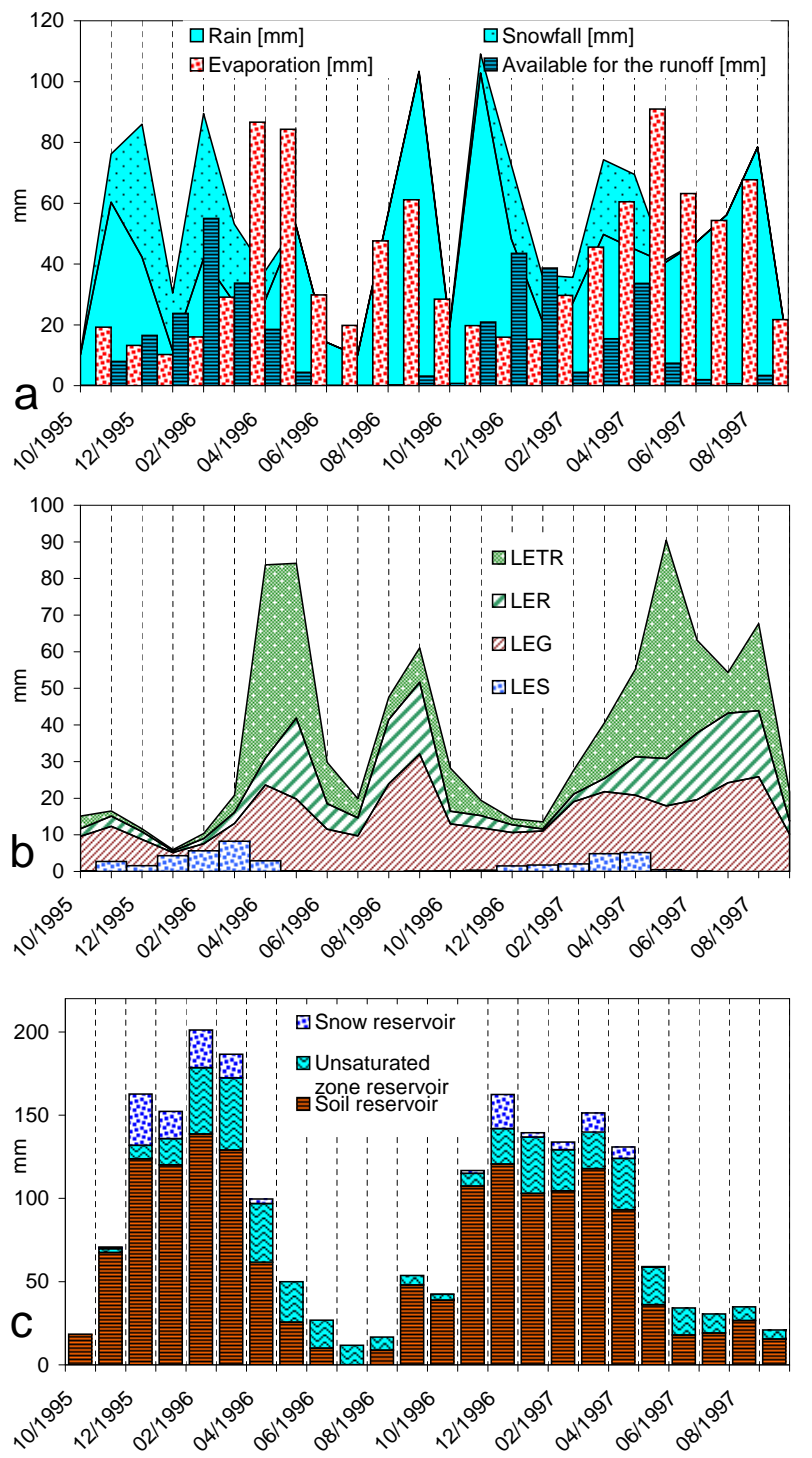

Fig. 7. Monthly evolution of the water budget of the whole basin: (a) Main water budget components - Rain and snow precipitation (stacked areas), Total evaporation and runoff; (b) Evaporation components: Bare ground evaporation ( $L E G)$, Plant transpiration $(L E T R)$, Intercepted water evaporation $(L E R)$ and evaporation/sublimation from snow surface (LES) (stacked columns representation except $L E S$ ); (c) Main water storage reservoirs' evolution: soil reservoir, unsaturated zone reservoir and snow reservoir (stack column representation). The unit for all the variables is $\mathrm{mm} / \mathrm{year}$.

\section{Conclusion}

The purpose of this project was to implement a coupled hydrometeorological model (ISBA-MODCOU) in Bulgaria, in order to study the variability of water and energy budgets.

The hydrometeorological model had been used in France, in association with the SAFRAN atmospherical analysis system. As such a system was not available in Bulgaria compre-
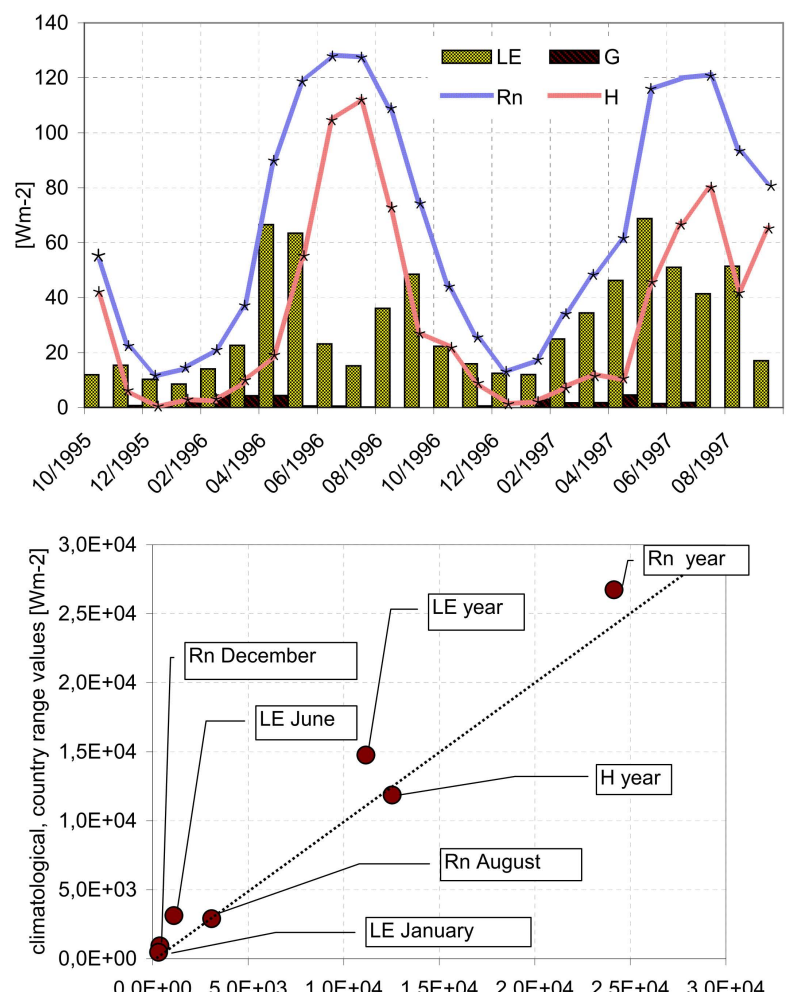

b

$0,0 \mathrm{E}+00 \quad 5,0 \mathrm{E}+03 \quad 1,0 \mathrm{E}+04 \quad 1,5 \mathrm{E}+04 \quad 2,0 \mathrm{E}+04 \quad 2,5 \mathrm{E}+04 \quad 3,0 \mathrm{E}+04$ basin range modelling results for 2 years $\left[\mathrm{Wm}^{-2}\right]$

Fig. 8. (a) Monthly values of the energy budget for the whole basin: $R_{n}$ - Net radiation flux $\left[\mathrm{Wm}^{-2}\right], L E-$ Latent heat flux $\left[\mathrm{Wm}^{-2}\right]$, $H$ - Sensible heat flux $\left[\mathrm{Wm}^{-2}\right], G-$ Ground heat flux $\left[\mathrm{Wm}^{-2}\right]$; (b) Basin area model energy budget components compared to climatological energy budget components for the country as a whole.

hensive work was done to generate a complete atmospheric database. It has been demonstrated that even with the relatively scarce meteorological network, the available data is qualitatively and quantitatively sufficient for the modelling.

A calibration of the shape parameter $(b)$, used in the subgrid runoff scheme, was carried out, taking into account its dependency on the cell elevation. In order to calibrate the amount of surface runoff, that represents the fast component of the riverflow, a relationship between the shape parameter (b) of the subgrid runoff scheme and the altitude was proposed and assessed.

In order to improve the simulation of the riverflows, a simplified scheme describing the impact of the unsaturated zone below the root-zone was added. It consists of two reservoirs fed by the drainage simulated by ISBA and allows simulation of the time delay for the transfer of water from the soil column to the aquifer or the river. As those reservoirs use the same daily time step as the hydrological model, their five parameters could be calibrated versus the observations, with high spatial resolution and short computing time.

The impact of the numerous dams and pumping the river was quantified thanks to the numerous data collected. Such 
impact has a clear annual cycle, and, for a given month, it can represent up to $4 \%$ of the annual discharge. Due to the precision of the data collected, the effects of the dams on the riverflow could be taken into account in the simulation.

The simulation was made over two annual cycles, and the validation was performed by using observed snow depth, snow water equivalent, daily riverflow, and soil moisture. The simulation was in good agreement with the observations. For instance, more than $25 \%$ of the river gauges were simulated with efficiency above 0.7 .

It may be concluded that the country experiences water stress in summer, which limits the evapotranspiration. Indeed, the annual Bowen ratio is rather high, between 1.36 (for 1995-1996) and 0.92 (for 1996-1997).

The results of this first application for the Maritsa, Tundzha and Arda basins in Bulgaria will be used in many ways:

- It is a first step for the implementation of an operational hydrological model that could be used for both monitoring and forecasting of water budget and riverflow. This is a priority after the inundations in August 2005 and March 2006. These events led to economical losses of more than $850 \times 10^{6} €$ in Bulgaria alone. In time of floods, after crossing the Bulgarian territory, Maritsa and its tributaries Arda and Tundzha rivers cause inundations in Turkey and Greece. Therefore the implementation of an efficient operational hydrological forecasting system in the region will have highly positive cross border impact.

- It allows to define the methodology and to estimate the amount of data needed for a long-term retrospective study. Such study is necessary to understand the characteristics of the water system in Bulgaria, and to be able to anticipate the impact of climatic change.

- To optimise the meteorological and hydrological network in order to reduce their maintenance cost since financial resources for public domain are a major issue.

Acknowledgements. The authors wish to acknowledge the financial support of Météo-France and Ecole Nationale Supérieure des Mines de Paris (ENSMP). The authors would like to express their deep gratitude to all colleagues from GMME/MC2 - division of the National Centre for Meteorological Research of Météo-France (CNRM), to T. Bojkova and the colleagues from NIMH for their suggestions and their help to obtain and prepare the necessary data sets for carrying out this study.

Edited by: J. D. Kalma

\section{References}

Antonov, Ch. and Danchev, D.: Underground waters in Popular Republic of Bulgaria. State Publishing House: Technika, Sofia 1980, 1980.

Artinian, E.: Modélisation hydrologique du bassin du Rhône. ENM, Météo-France, Rapport de mastère, décembre 1996, Toulouse, 1996.

Benichou, P. and Le Breton, Od.: Prise en compte de la topographie pour la cartographie des champs pluviométriques statistiques, in: La Météorologie, 7e série, n 19, octobre 1987, 1987.

Boone, A. and Etchevers, P.: An intercomparison of three snow schemes of varying complexity coupled to the same land surface model: local-scale evaluation at an alpine site, J. Hydrometeorol., 4, 374-394, 2001.

Champeaux, J.-L. and Legléau, H.: Vegetation mapping over Europe using NOAA/AVHRR, in: The 1995 meteorological satellite data user's conference, pages 139-143, Winchester, UK, EUMETSAT, 1995.

Delfiner, P., Renard, D., and Chiles, J. P.: BLUEPACK-3D Manual: Centre de Géostatistique, Fontainebleau, France, 1978.

Dimitrova, Yu.: Bulk density and changes depending on the moisture with different mechanical and humus soil composition, Soil science and agrochemistry, XXVI, 3-4, Sofia, 1991.

Douville, H., Royer, J.-F., and Mahfouf, J.-F.: A new snow parameterisation for the Météo-France climate model. Part I: Validation in stand-alone experiments, Climate Dyn., 12, 21-35, 1995.

Dûmenil, E. and Todini, L.: A rainfall-runoff scheme for use in the Hamburg climate model, in: Advances in Theoretical Hydrology, a tribute to James Dooge, edited by: O'Kane, J. P., page 462, McGraw-Hill, New York, 1992.

Etchevers, P., Golaz, C., and Habets, F.: Simulation of the water budget and the riverflows of the Rhone basin from 1981 to 1994 , J. Hydrol., 244, 60-85, 2000.

Golaz, C., Etchevers, P., Habets, F., Ledoux, E., and Noilhan, J.: Comparison of two hydrological simulations of the Rhone basin, Phys. Chem. Earth, 26(5-6), 461-466, 2001.

Habets, F., Noilhan, J., Golaz, C., Goutorbe, J. P., Lacarrère, P., Leblois, E., Ledoux, E., Martin, E., Ottlé, C., and Vidal-Madjar, D.: The ISBA surface scheme in a macroscale hydrological model applied to the Hapex-Mobilhy area. Part I : model and data base, J. Hydrol., 217, 75-96, 1999a.

Habets, F., Noilhan, J., Golaz, C., Goutorbe, J. P., Lacarrère, P., Leblois, E., Ledoux, E., Martin, E., Ottlé, C., and Vidal-Madjar, D.: The ISBA surface scheme in a macroscale hydrological model applied to the Hapex-Mobilhy area. Part II: simulation of streamflows and annual water budget, J. Hydrol., 217, 75-96, $1999 b$.

Hershkovich, E., Stephanov, I., Ganeva, B., et al.: Agro-climatical atlas of Bulgaria, Mean Direction of Hydrology and Meteorology - Bulgarian Academy of Sciences, Institute of Hydrology and Meteorology, Institute of Cartography, Sofia, 1982.

Hottel, H. C.: A Simple Model for Estimating the Transmittance of Direct Solar Radiation Through Clear Atmospheres, Solar Energy, 18, 129-134, 1976.

Kalinova, M.: Unconfined underground waters, in: Geography of Bulgaria - Physical Geography, 1982: Natural Conditions and Resources, Bulgarian Academy of Sciences, p. 259, Sofia, 1982.

Kasten, F. and Czeplak, G.: Solar and terrestrial radiation dependent on the amount and type of cloud, Solar Energy, 24, 177-189, 
1979.

Ledoux, E., Girard, G., and Marsily, G.: Spatially distributed modelling: conceptual approach, coupling surface water and groundwater, in: Unsaturated Flow in Hydrologic Modelling Theory and Practice, edited by: Morel-Seytoux, H. J., by Kluwer Academic Publishers, 1989.

Lingova, S.: The regime of the Radiation and the Light in Bulgaria, Bulgarian Academy of Sciences, 56-62, Sofia, 1981.

Machkova, M. and Dimitrov, D.: Book of reference for the quantitative characteristics of the underground waters for the period 1980-1996, National Institute of Meteorology and Hydrology, Sofia, 1999.

Morel, S.: Modélisation distribuée du bilan hydrique a l'échelle régionale: application au bassin Adour Garonne, Doctoral Thesis, Toulouse 3 University, 2003.

Nash, J. E. and Sutcliffe, J. V.: Riverflow forecasting through conceptual models, 1, a discution of principles, J. Hydrol., 10(3), 282-290, 1970.

Ninov, N.: Soils in the mountain area in: Geography of Bulgaria - Physical Geography, 1982: Natural Conditions and Resources, Bulgarian Academy of Sciences, 380-388, Sofia, 1982.

Noilhan, J. and Lacarrère, P.: GCM gridscale evaporation from mesoscale modelling, J. Climate, 8(2), 206-223, 1995.

Noilhan, J. and Planton, S.: A simple parameterization of land surface processes for meteorological models, Mon. Wea. Rev., 117, 536-549, 1989.
Richards, L. A. and Wadleigh, C. H.: Soil water and plant growth, in: Soil Physical Conditions and Plant Growth, edited by: Shaw, B. T., American Society of Agronomy Series Monographs Volume II, 74-251, Academic Press, New York, 1952.

Rousset, F., Habets, F., Gomez, E., Le Moigne, P., Morel, S., Noilhan, J., and Ledoux, E.: Hydrometeorological modeling of the Seine basin using the SAFRAN-ISBA-MODCOU system, J. Geophys. Res., 109, D14105, doi:10.1029/2003JD004403, 2004.

Staley, D. and Jurica, G.: Effective atmospheric emissivity under clear skies, J. Appl. Meteor., 11, 349-356, 1972.

Troshanov, N.: Hidden discharge evaluation of the North Rhodopes karstic water to the Upper Thracian lowland, Engineering Geology and Hydrogeology, 22, 10-27, Sofia, 1992.

Vekilska, B. and Kalinova, M.: Snow pack in the West Stara Planina Mountain and its impact on the riverflow, Problems of the Geography of P. R. of Bulgaria 5, Sofia, Nauka i Izkustvo, 1978.

Vekilska, B.: Radiation and heat budget in: Geography of Bulgaria Physical geography, Natural conditions and resources, 1982,169-171, Bulgarian Academy of Sciences, Sofia, 1982.

Yordanova, M.: Genesis and monthly partition of the riverflow in the East Rhodopy Mountain - a result from the complex effect of the physical and geographical factors, Thesis, Geographical Institute, Bulgarian Academy of Sciences, 1978.

Zyapkov, L.: Water budget of the river basins, in: Geography of Bulgaria - Physical Geography, 1982: Natural Conditions and Resources, p 327, Bulgarian Academy of Sciences, Sofia, 1982. 